\title{
How landscape ecology can promote the development of sustainable landscapes in Europe: the role of the European Association for Landscape Ecology (IALE-Europe) in the twenty-first century
}

\author{
Marc Antrop • Jesper Brandt • Isabel Loupa-Ramos • \\ Emilio Padoa-Schioppa · Jonathan Porter • \\ Veerle Van Eetvelde · Teresa Pinto-Correia \\ Received: 12 March 2013/Accepted: 24 June 2013/Published online: 18 October 2013 \\ (C) Springer Science+Business Media Dordrecht 2013
}

\begin{abstract}
In Europe, landscape research has a long tradition of drawing on several disciplines. 'National schools' of landscape research developed, which were related to the characteristic landscapes found in the different countries and to specific linguistic meanings and legal traditions when using landscape related concepts. International co-operation demands a certain harmonization of these concepts for better mutual understanding. The 2000 European Landscape Convention provided an important momentum to rethink research, policy and management of landscapes from the perspective of sustainable development and participatory planning. Landscape ecology as a transdisciplinary science with a dynamic and holistic perspective on landscape offers a great potential for an integrative approach. The specificity of the
\end{abstract}

M. Antrop $(\bowtie) \cdot$ V. Van Eetvelde

Department of Geography, Ghent University,

Krijgslaan 281-S8, 9000 Ghent, Belgium

e-mail: marc.antrop@ugent.be

J. Brandt

ENSPAC, Roskilde University, PO Box 260,

4000 Roskilde, Denmark

I. Loupa-Ramos

CESUR/Instituto Superior Técnico, Av.

Rovisco Pais, 1049-001 Lisbon, Portugal

E. Padoa-Schioppa

Research Unit of Landscape Ecology,

University of Milano-Bicocca, Piazza Della Scienza 1,

20126 Milan, Italy
European landscape research rests on its long history and on integration based on the great diversity of the landscapes, characterised by an intimate relationship between the varied natural environment and the different cultural traditions which define the identity of countries, regions and people. Within a unified Europe, with increasing international and trans-border co-operation and increasing common environmental problems, the creation of a specific European Association for Landscape Ecology (IALE-Europe), in addition to the existing international association and its national chapters, became justified by the need for a collaborative endeavour to address the specific problems of landscapes in Europe and to stimulate cooperation between landscape ecologists in research, education and practice.

\author{
J. Porter \\ Countryscape, 125 Ducie House, Ducie Street, \\ Manchester, UK \\ T. Pinto-Correia $(\bowtie)$ \\ ICAAM/Instituto de Ciências Agrárias e Ambientais \\ Mediterrânicas, Universidade de Évora, \\ Núcleo da Mitra, Apartado 94, \\ 7002-774 Évora, Portugal \\ e-mail: mtpc@uevora.pt
}


Keywords Europe's landscapes and identity · European Landscape Convention ·

Transdisciplinarity

\section{Why IALE-Europe?}

This article reflects upon the tradition of landscape research in Europe, and the reasons underlying the specific attributes of this research, justifying the organization of European landscape ecologists in an united European chapter within IALE - the International Association for Landscape Ecology. The coordinated endeavour to sustain the specificity of European landscapes, their history, use, heritage value, conservation, emerging research and policy issues, and to master their constant on going changes justified the founding of the association in addition to the existing International Association (IALE) and its national chapters. IALE-Europe was also influenced by the varied development of the scientific discipline of landscape ecology, by the concept of landscape and its multiple interpretations in a multi-lingual Europe and the growing need to mobilise and integrate these different traditions in the common efforts to meet the changing demands for research, planning, management and policy in a rapidly transforming world. Further, strengthening the European dimension is also aimed at facilitating research on broad scale landscape systems in Europe, that cross country boundaries and are particular for Europe, and on gradients that are particularly expressed in European landscapes. Finally, IALE-Europe provides a way for landscape ecologists who do not have a country chapter to collaborate on important landscape issues with colleagues in other parts of Europe dealing with similar issues.

\section{Landscape ecology: its European roots}

Before the second world war, the German geographer Carl Troll developed a holistic and integrated methodological approach for studying landscapes using the then emerging technique of aerial photography which provided a new way of observing the face of the earth (Troll 1939, 1950). He introduced the term Landschaftsökologie and called it an 'Anschauungsweise', 'a way of looking' at the landscape from a combined ecological and geographical perspective resulting in a holistic and interdisciplinary synthesis.
After the second world war, this integrative approach was suppressed by the continuing specialisation that was taking place in all the sciences. But it gradually became clear that environmental problems and societal demands on the landscape are too complex to be solved by a single discipline. This was the main topic of discussion during an international and multidisciplinary congress on 'Perspectives in Landscape Ecology-Contributions to research, planning and management of our environment' held in Veldhoven (the Netherlands) in April 1981 (Tjallingii and de Veer 1982). As a result, the broken link within the tradition of landscape ecology as defined by Troll was re-established leading to the formal creation of the discipline of landscape ecology which integrated many different disciplines dealing with landscape research. In October 1982, the International Association of Landscape Ecology (IALE) was founded in Piešt'any (Slovakia), and was based on an emerging cooperation between Western and Eastern Europe. The resulting ideas about landscape ecology were rapidly reconceived in a North American context by different specialists dealing with the landscape.

All over the world, humans have constantly been changing the natural environment and created cultural landscapes. These were accustomed by the geographical settings and the mode of subsistence, depending on available technology and social organisation. The extremely varied geographical setting in the European continent, and especially the many comprehensive marine inlets, has been highlighted as important conditions for an upcoming capitalist mode of production and a globalizing trade. In the new parts of the world that were taken into possession by European nations, the development of cultural landscapes was mainly inspired by the European traditions, neglecting local pre-colonial cultural landscape development, often considered as more or less pristine and of minor relevance for the new ruling class. In Europe, however, most cultural landscapes have a long historical tradition and are considered an expression of culture and power, containing many symbolic meanings both in the natural and cultural heritage they represent. Nevertheless, many of these landscapes have rapidly been transformed and simplified in the last decades by land use intensification and increasing urbanisation. The traditional landscapes that still remain are rapidly losing their ecological and heritage values, considered as 'natural and cultural capitals' 
which are important for local and regional identities. At the same time, new landscapes are being created, resulting from new combinations of drivers, again in high levels of complexity due to the interplay of multiple transition processes occurring in each place. Due to these different trends, landscape analysis has progressively been 'discovered' by multiple disciplines, such as archaeology, landscape architecture, planning, economy, and a whole range of human sciences, which previously had no tradition in landscape research.

Today many disciplines are involved in landscape research. Landscape ecology has evolved as a widely recognised distinctive approach among these cooperating disciplines. However, there are many transitions between the different approaches in landscape research and its application, which for most is the domain of planning, management and policy. Therefore landscape ecology should be flexible and recognise its strengths and weaknesses in the scope of this broader landscape research. The European Landscape Convention (ELC), adopted by the European Council in Council of Europe (2000), has decisively brought landscape issues into the arena in which different disciplines intermingle. This is because it clearly positions the landscape in the interaction between natural and cultural factors, both in its material and mental representations. More than 10 years after its signature, the ELC is broadly accepted as the shared European understanding of the landscape. The ELC shows the need for a more ecological approach, but also for assessing the social and cultural aspects of the landscape, which demands research methods from natural as well as from social sciences and humanities.

\section{Landscape research in Europe: a long tradition}

When Troll introduced the concept of landscape ecology, he formulated a new approach, which was based on a holistic view using aerial photo-interpretation, in the already long tradition of 'landscape science'. Although descriptions and representations of landscapes in Europe date back to the fourteenth century, scientific research concerning landscapes began with the development of natural sciences during the nineteenth century. It was strongly influenced by naturalists' explorations such as those by von Humboldt and Darwin, as well as by Kant's philosophy.
Landscape research became a core topic in the emerging geographical science. The term Landschaftskunde was introduced by the German geographer Oppel in 1884 and an important German school of landscape research developed focussing on theoretical concepts for the description and analysis of the relations between the 'natural' and 'cultural' landscape. The large variety of landscapes and of languages and cultures meant that very different 'national' schools of landscape research emerged.

The first international network of academics studying the European landscapes was the Permanent European Conference for the Study of the Rural Landscape (PECSRL) founded in 1957. The focus is on issues in historical geography, although also other disciplines such as landscape architecture are active. The main purpose is to exchange knowledge by facilitating personal contacts. More recently, it functions as a forum for new initiatives in European landscape research and landscape management and stimulates cooperation between researchers, managers and policy makers. PECSRL organises a bi-annual conference. Later, in 1967, the Landscape Research Group (LRG) was founded as a charity aiming to promote landscape research in the broadest perspective for public benefit. Landscape research developed rather independently in eastern and western Europe due to the cold war. In Eastern Europe, the Centre of Biological-Ecological Sciences, Slovak Academy of Sciences in Bratislava in former Czechoslovakia organized international symposia on landscape ecological research every third year since 1967.

Over the last 20 years, several European networks have been set up dealing with landscape research from different perspectives, such as research and expertise, and specific themes such as rural and agricultural landscapes, history and archaeology, design, architecture and planning. Each of these groups organizes its own conferences and workshops.

\section{Landscape: subtleties of languages}

The word 'landscape' emerged in the Germanic languages during the thirteenth century and refers etymologically to an organised area of land, managed in a specific way giving it a proper character and related to which certain rules applied. Since the renaissance, pictorial representations of the landscape 